\title{
Evaluation of Impact of Chelated Mineral Mixture Formulation Supplementation on Milk Quantity and Milk Quality Parameters in Lactating Dairy Cows under Field Conditions
}

A. Nazeer Ahmed, Vishwanath Gopal Bhagwat, Rangesh Paramesh

10.18805/ajdfr.DR-1808

\begin{abstract}
Background: The primary aim of the present study is to evaluate the effect of chelated organic mineral mixture "HimChelate" (Developed by Himalaya Wellness Company) on milk production, fat percentage, solids not fat (SNF) and milk somatic cell counts in lactating dairy cows.

Methods: A total of eight lactating dairy cows were randomly selected in one group $(G)$ supplemented with HimChelate mixed with concentrate feed and water at a dose of $30 \mathrm{~g} /$ day/cow. The cows were used as their controls and thus, allocated to a control pretreatment period (baseline; 7 days), followed by a treatment period (30 days) and after the treatment period ( 7 days). The impact of HimChelate supplementation on milk production and quality parameters viz, fat and SNF percentages were before supplementation (baseline), during the supplementation period of HimChelate daily up to 4 weeksand after supplementation of HimChelate (1 week) were accessed to evaluate the efficacy of HimChelate.

Result: The mean milk yield in $G$ on the baseline and during the treatment period, i.e., weeks $1,2,3$ and 4 , was $10.64 \pm 1.34$ and $10.72 \pm 1.36,10.76 \pm 1.35,10.79 \pm 1.37$ and $10.73 \pm 1.40$, respectively. The sum milk yield was increased moderately in $G$ during the treatment period compared with that on the baseline throughout the treatment period, i.e., $0.58 \mathrm{~L}$ (week 1), $0.93 \mathrm{~L}$ (week 2 ), $1.20 \mathrm{~L}$ (week 3) and $0.68 \mathrm{~L}$ (week 4). The impact of HimChelate on assessment parameters, such as milk yield, fat and SNF in dairy cows showed that mean milk yield (L) was increased by $1.03 \%$ following supplementation of HimChelate at $30 \mathrm{~g}(\mathrm{G})$ once daily per cow, respectively. Conversely, fat and SNF percentages were increased by $4.41 \%$ and $0.25 \%$ following the supplementation of HimChelate at $30 \mathrm{~g}(\mathrm{G})$. The supplementation of HimChelate $30 \mathrm{~g}$ once daily caused a slight reduction in milk somatic cell count (SCC) as early as day $3(5100000 \mathrm{cell} / \mathrm{s} / \mathrm{mL})$. Conversely, the major reduction in milk SCC count was observed from day 9, i.e., $900000 \mathrm{cells} / \mathrm{mL}$ and maintained milk SCC of 300000 cells $/ \mathrm{mL}$ from days 12 to 21 . The findings of present research investigation depicted that the supplementation of HimChelate at the dose of $30 \mathrm{~g} /$ day/cow was better in terms of augmentation of milk production and improvement of milk quality parameters.
\end{abstract}

Key words: Fat, Herbal galactagogues, HimChelate, Lactating cows, SNF, Somatic cell counts.

\section{INTRODUCTION}

Organic trace mineral supplementation in dairy diets has been shown to be beneficial in both study and practice.

Traditional inorganic forms of trace minerals dissolve quickly in the rumen and are free to interact with antagonists, causing trace minerals to be lost before being absorbed by the animal (Formigoni et al. 2011). Chelated organic trace minerals are held together by coordinating covalent connections with the organic ligand. The interactions between the ligand and the mineral can be prevented by the ligand-mineral bonds, which improves the mineral's bioavailability (El Ashry et al. 2012).

The claimed enhanced bioavailability of organic vs. inorganic sources of trace minerals is the fundamental argument for employing organic forms of trace minerals. Although published findings on the availability of organic and inorganic minerals have been inconsistent, there is some evidence that supplementing with organic minerals has benefits. Organic trace minerals appear to be beneficial and advantageous in conditions involving antagonistic minerals, such as high levels of Mo, S, Fe, or $\mathrm{Zn}$ interfering with $\mathrm{Cu}$ availability. When mineral antagonists are detected,
Veterinary Hospital, Jalamangala, Ramanagar-562 120, Karnataka, India.

Corresponding Author: Vishwanath Gopal Bhagwat, Himalaya Wellness Company, Makali, Bengaluru-562 162, Karnataka, India. Email: dr.bhagwat@himalayawellness.com

How to cite this article: Ahmed A.N., Bhagwat, V.G. and Paramesh, R. (2022). Evaluation of Impact of Chelated Mineral Mixture Formulation Supplementation on Milk Quantity and Milk Quality Parameters in Lactating Dairy Cows under Field Conditions. Asian Journal of Dairy and Food Research. DOI: 10.18805/ajdfr.DR-1808.

Submitted: 17-09-2021 Accepted: 23-12-2021 Online: 29-01-2022

water quality must be considered. Chelated minerals are administered mainly during times of high nutritional demand, such as pregnancy, lactation, weaning, reproductive stress, rapid growth, environmental stress (such as temperature and humidity), or disease-challenged conditions (Rabiee et al. 2010). Chelates have been studied regarding their effect on improved immunity (less disease or sickness), reproductive performanceand herd health. To maximize the absorption of these trace minerals from the chelated 
Evaluation of Impact of Chelated Mineral Mixture Formulation Supplementation on Milk Quantity and Milk Quality...

compounds, they should be highly stable in the rumen (Mirzaei and Venkatesh. 2012).

Chelates are stable, electrically neutral complexes, which protect trace minerals from chemical reactions during digestion that would render the mineral unavailable to the animal. Added minerals complexed with organic ligands thus are used to increase the bioavailability and uptake. The chelated mineral reaches the plasma intact and separates at the site of action. Chelated trace minerals are suitable for use in all species. They can replace $25 \%-40 \%$ of the supplementary inorganic minerals to provide highly available trace minerals (Lisgara et al. 2016).

It was understood from the literature survey that there is a resurgence to research and develop chelated organic trace minerals for augmenting production performances of livestock. With this background, this trial was designed to evaluate the effect of chelated organic mineral mixture "HimChelate" (developed by Himalaya Wellness Company) on milk production, fat percentage, SNF and milk somatic cell counts in lactating dairy cows.

\section{MATERIALS AND METHODS \\ Chelated minerals formulation}

HimChelate is a proprietary chelated mineral mixture formulation developed by Himalaya Wellness Company, Bengaluru, India. It is mainly composed of chelated minerals and other trace minerals $(\mathrm{Zn}, \mathrm{Cu}, \mathrm{Mn}, \mathrm{Se}, \mathrm{Co}, \mathrm{K}, \mathrm{Fe}, \mathrm{Mg}$, $\mathrm{Cr}, \mathrm{Na}, \mathrm{Ca}$ and $\mathrm{P}$ ) and vitamins (A, D3, E and niacinamide) fortified with herbs, namely, Shatavari (Asparagus racemosus), Amalaki and Methi (Trigonella foenum graecum).

\section{Ethical committee approval}

This study was conducted according to guidelines laid down for the care and use of animalsand the study protocol was approved by the Institutional Animal Ethics Committee, Himalaya Wellness Company, Bangalore, Protocol No. 06/ LA/COWS/15.

\section{Study subjects}

A total of eight lactating dairy cows of Holstein Friesian cross breeds with ages between 2.5 and 7.0 years and parity between 1 and 3 . The study was conducted between June 2015 to August 2015 at Ramanagara veterinary Hospital area, Karnataka, India. Cows with the absence of gag reflex and severe disease conditions such as tuberculosis and prolapse were excluded from this study.

\section{Study design and experimental details}

A total of eight selected lactating dairy cows in one group (G) were supplemented with HimChelate mixed with concentrate feed and water at a dose of $30 \mathrm{~g} /$ day/cow. The cows were used as their controls and, therefore, allocated to a control pretreatment period (baseline; 7 days), followed by a treatment period ( 30 days)and after the treatment period (7 days). When HimChelate was supplemented to dairy cows, concurrent supplementation with other chelated minerals-based products was not followed.

\section{Evaluation of study parameters}

\section{Milk production}

The impact of HimChelate supplementation on milk production was assessed by recording the actual milk production in liters $(\mathrm{L})$ before supplementation (baseline), during the supplementation period of HimChelate on a daily basis up to 4 weeksand after supplementation of HimChelate (1 week).

\section{Milk quality parameters}

The impact of HimChelate supplementation on milk quality parameters, such as fat and SNF percentagesand milk somatic cell counts (cells $/ \mathrm{mL}$ ) were assessed before supplementation (baseline), during the supplementation period of HimChelate on a daily basis for up to 4 weeksand after supplementation of HimChelate (1 week).

\section{Determination of fat}

The fat content of milk was determined using the Gerber method. Fat content (colorless column) was measure directly from the butyrometer stem by deducting the lowest figure from highest, as described in IS: 1224 (Part-I), 1977.

\section{Determination of SNF}

SNF percentage in milk is calculated using the following formula:

$$
\operatorname{SNF}(\%)=\mathrm{CLR} / 4+0.25 \mathrm{~F}+0.44
$$

Where

$\mathrm{F}=\mathrm{F}$ at content of milk.

SNF = Solids-not-fat in milk.

$\mathrm{CLR}=$ Corrected lactometer reading at $27^{\circ} \mathrm{C}$.

\section{Somatic cell count}

The milk samples were collected before treatment and during the treatment period, i.e., days $3,6,9,12,15,18$ and 21 as described by Singh et al. (2019).

\section{Statistical analysis}

The data are expressed as mean \pm SEM. Milk yield data were subjected to repeated measures one-way analysis of variance (ANOVA) followed by Dunnett's multiple comparison post hoc tests to assess the impact of HimChelate on milk yield between baseline; during the treatment period, i.e., week 1 of supplementation and subsequent weeks i.e., weeks 2,3 and 4 and after the treatment period. Additionally, an unpaired Students $t$-test was applied to evaluate the dosage effect of HimChelate on milk yield and milk quality parameters. $P \leq 0.05$ was considered statistically significant.

\section{RESULTS AND Disscussion}

The sum milk yield $(L)$ and mean milk yield (L, mean \pm SEM) observed in dairy cows $(n=8)$ before HimChelate supplementation (baseline) in $\mathrm{G}$ were 85.16 and $10.64 \pm 1.34$, respectively. A gradual increase in milk yield was recorded upon the supplementation of HimChelate in concentrated feed to dairy cows over 4 weeks compared with baseline 
values. The mean milk yield in $\mathrm{G}$ on the baseline and during the treatment period, i.e., week 1 , week 2 , week 3 and week 4 , was $10.64 \pm 1.34$ and $10.72 \pm 1.36,10.76 \pm 1.35,10.79 \pm 1.37$ and $10.73 \pm 1.40$, respectively. The sum milk yield was increased moderately in $\mathrm{G}$ during the treatment period compared with that on the baseline throughout the treatment period, i.e., $0.58 \mathrm{~L}$ (week 1), $0.93 \mathrm{~L}$ (week 2), 1.20 L (week 3) and $0.68 \mathrm{~L}$ (week 4). However, the mean milk yield ( $\mathrm{L}$, mean \pm SEM) and the sum milk yield (L) were reduced after the supplementation period of HimChelate at $30 \mathrm{~g} /$ day/cow (G)

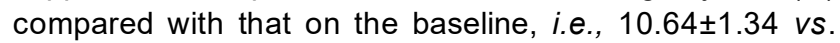
$10.53 \pm 1.40$ and -0.88 , respectively (Table 1 ).

The impact of HimChelate on assessment parameters, such as milk yield, fat and SNF in dairy cows showed that mean milk yield $(L)$ was increased by $1.03 \%$ following the supplementation of HimChelate at $30 \mathrm{~g}(\mathrm{G})$ once daily per cow. Conversely, fat and SNF percentages were increased by $4.41 \%$ and $0.25 \%$ following the supplementation of HimChelate at $30 \mathrm{~g}(\mathrm{G})$, respectively (Table 2 and Fig 1). Furthermore, the results of milk SCC depicted that before the supplementation of HimChelate (day 0), milk SCC was almost 8100000 cells $/ \mathrm{mL}$. However, the supplementation of HimChelate caused a slight reduction in milk SCC as early as day 3 (5100000 cells $/ \mathrm{mL})$. Conversely, a major reduction in milk SCC count was observed from day 9 , i.e., 900000 cells $/ \mathrm{mL}$ and maintained milk SCC of 300000 cells/ $\mathrm{mL}$ from days 12-21 (Fig 2).

Overall, the findings of our investigation depicted that the supplementation of HimChelate at a dose of $30 \mathrm{~g} /$ day/ cow was better in terms of augmentation of milk production and improvement of milk quality.

Organic minerals have several beneficial effects, such as production enhancement, increased milk yield qualityand reproductive efficiency in ruminants (Marques et al. 2016; Hackbart et al. 2010). The progressive effects of organic minerals on animal performance seem mainly due to higher bioavailability than inorganic sources. Several research activities conducted in different livestock species using the vibrant sources of different mineral elements revealed significant differences in the bioavailability of organic and inorganic minerals (Wang et al. 2010; Feng et al. 2010; Yatoo et al. 2013). Thus, the primary aim of this study is to evaluate the effect of chelated organic mineral mixture "HimChelate" (developed by Himalaya Wellness Company) on milk production, fat and SNF percentageand milk somatic cell counts in lactating dairy cattle under field conditions.

In this study, milk yield (L) was increased by $1.03 \%$ following the supplementation of HimChelate at $30 \mathrm{~g} /$ day/ cow. Simultaneously, fat and SNF percentages increased by $4.41 \%$ and $0.25 \%$ following the supplementation of HimChelate at $30 \mathrm{~g}$, respectively. These findings were comparable with the results of several other researchers reported in the literature. Hackbart et al. (2010) and Somkuwar et al. (2011) reported that binding $\mathrm{Cu}, \mathrm{Zn}, \mathrm{Fe}$ and $\mathrm{Mn}$ with amino acids and peptides could boost the bioavailability of these trace minerals, thereby improving milk production of livestock. The effect on milk supplementing cows with organic trace minerals in place of inorganic minerals increased milk yield and milk fat level (Marques et al. 2016; Hackbart et al. 2010). With the same level of supplementation to cows: $\mathrm{Zn}(15 \mathrm{mg} / \mathrm{kg}), \mathrm{Mn}(20 \mathrm{mg} / \mathrm{kg})$ and $\mathrm{Cu}(10 \mathrm{mg} / \mathrm{kg})$ from chelated sources resulted in higher milk yield $(11 \%)$, milk fatand protein percentages (both approximately $7 \%$ ) than those of inorganic sources (El Ashry et al. 2012). Hassan et al. (2011) reported that supplementation with $40 \%$ less $\mathrm{Zn}$ from chelated sources in ewes increased milk yield by $12 \%$ and protein and fat production by $26 \%$ and $31 \%$ in comparison with those of inorganic zinc sulfate sources. In cows in late lactation, less mineral supplementation to a tone of $40 \%$ from chelated sources resulted in a $4 \%$ increase in milk yield when compared with $100 \%$ inorganic minerals Somkuwar et al. (2011). Improvement in milk production and component can

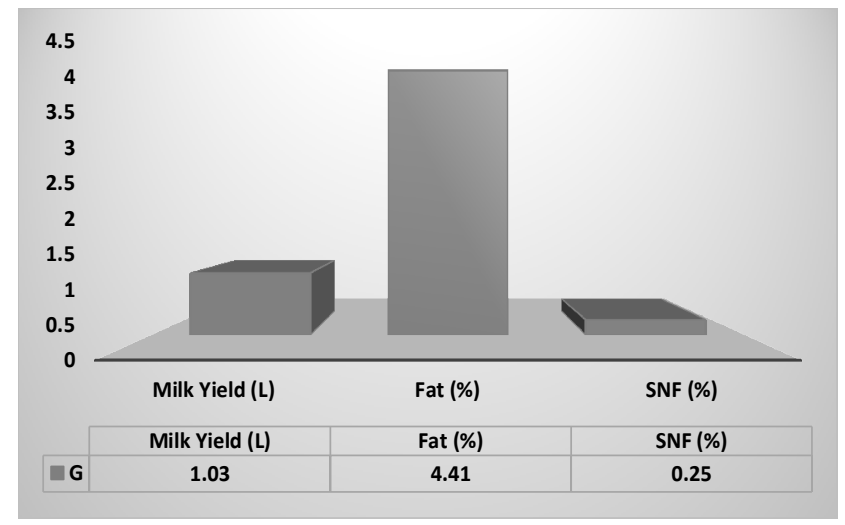

Fig 1: Percentage improvement in milk yield, fat and SNF percentages (before treatment to during treatment).

Table 1: Overall impact of HimChelate on milk yield in dairy cows.

\begin{tabular}{lcccccc}
\hline \multirow{2}{*}{ Parameter } & & \multicolumn{2}{c}{ During the treatment period of HimChelate } & \multicolumn{2}{c}{$\begin{array}{c}\text { After } \\
\text { treatment }\end{array}$} \\
\cline { 3 - 5 } Sum milk yield $(\mathrm{L})$ & Baseline & Week 1 & Week 2 & Week 3 & Week 4 & 84.28 \\
Mean milk yield (L) & 85.16 & 85.74 & 86.09 & 86.36 & 85.84 & $10.53 \pm 1.40$ \\
Sum milk yield Increase compared & $10.64 \pm 1.34$ & $10.72 \pm 1.36$ & $10.76 \pm 1.35$ & $10.79 \pm 1.37$ & $10.73 \pm 1.40$ & -0.88 \\
with that on the baseline $(\mathrm{L})$ & - & 0.58 & 0.93 & 1.2 & 0.68 &
\end{tabular}

Values are expressed as mean \pm SEM; $n=8$.

$P>0.05$ compared with baseline values based on repeated measures one-way ANOVA followed by Dunnett's multiple comparison test. 
Evaluation of Impact of Chelated Mineral Mixture Formulation Supplementation on Milk Quantity and Milk Quality...

be partially attributed to improved udder health and reduction of somatic cell count. Sobhinard et al. (2010) reported that somatic cell count was reduced by adding $\mathrm{Zn}$ methionine complex to the diet; this implies that $\mathrm{Zn}$ methionine plays an integral role in immune function by activating $T$ lymphocyte responsiveness, thus impacting the effectiveness of somatic cells within the mammary gland.

Furthermore, improvement in milk yield in our study following the supplementation of HimChelate could be attributed to the herbal galactogogues, such as Shatavari (Asparagus racemosus), Amalakiand Methi (Trigonella foenum-graecum), present in HimChelate. Galactagogue is a substance that encourages dairy cows to produce milk. They work by inhibiting hypothalamic dopaminergic receptors or dopamine-producing neurons, which influences the adreno-hypothalamo-hypophyseal-gonadal axis. By inhibiting dopamine receptors, these drugs boost prolactin production (Patel et al. 2016). Galactogogues increase secretory activity and thereby restore and regulate milk production by stimulating alveolar tissue activity (Ravikumar and Bhagwat. 2008). Different herbs can be used as a component of animal feed to improve animal productivity. Plants with galactagogue characteristics, such as Shatavari (Asparagus racemosus), Jivanti (Leptadenia reticulata)and Methi (Trigonella foenum-graecum), are commonly utilized as animal feed additives nowadays (Patel et al. 2016).

Table 2: Impact of different doses of HimChelate on assessment parameters in dairy cows.

\begin{tabular}{lccc}
\hline \multirow{2}{*}{ Parameter } & \multicolumn{3}{c}{ G: HimChelate- $30 \mathrm{~g}$ once daily } \\
\cline { 2 - 4 } & Baseline & $\begin{array}{c}\text { During } \\
\text { treatment }\end{array}$ & $\begin{array}{c}\text { After } \\
\text { treatment }\end{array}$ \\
\hline Milk yield (L) & $10.64 \pm 1.34$ & $10.75 \pm 1.37$ & $10.53 \pm 1.40$ \\
Fat (\%) & 3.40 & 3.55 & 3.66 \\
SNF (\%) & 7.79 & 7.81 & 7.81 \\
\hline
\end{tabular}

Values are expressed as mean \pm S.E.M; $\mathrm{n}=8$.

$P>0.05$ compared with baseline values based on the unpaired $t$-test.
Shatavari's pharmacology is galactagogue and mammogenic in general. It raises blood prolactin levels and encourages mammary gland cellular division (Ravikumar and Bhagwat 2008). Supplementing lactating crossbred cows with Galactin (50 g/day/animal), a Shatavari-based polyherbal galactagogue, enhanced milk output (Mirzaei and Venkatesh. 2012). In buffaloes and crossbred cows, the feeding herbal formulation contains $25 \%$ Shatavarienhanced milk production (25.10 percent) as well as a considerable boost in daily milk yield. Furthermore, polyherbal supplementation with Shatavari at $150-200 \mathrm{mg} /$ $\mathrm{kg}$ body weight improves fat, protein, lactoseand SNF yield in Karanfries cows during supplementation, residual and post residual periods in fed-group controls (Sharma, 2010). In crossbred cattle, supplementing with Milkplus, a Shatavaribased herbal treatment, increased milk output from 8.26 to 10.11 L/day (Sukanya et al. 2014). Similarly, Methi (Trigonella foenum-graecum) has been used as a galactagogue for millennia. Furthermore, this herb has been demonstrated to have a considerable impact on ruminant lactation performance (Tabares et al. 2014). Fenugreek supports milk production as it is a rich source of essential fatty acids Patel et al. (2017). Supplementing milk with fenugreek seeds improves the composition of cow's milk. Furthermore, fenugreek seed, which contains phytoestrogens, which are plant chemicals similar to the female sex hormone estrogen, an essential compound, diosgenin, has been experimentally shown to upsurge milk flow and increase daily return by supplementation of Shatavari, Jivantiand fenugreek in equal proportion at the dose rate of $60 \mathrm{~g} /$ day in lactating Kankrej cows (Patel et al. 2017).

In this study, there was a major reduction in milk SCC following the supplementation of HimChelate for nine consecutive days. This could be due to the bioavailability of chelated minerals of HimChelate especially $\mathrm{Zn}, \mathrm{Cu}$ and Se, since study report shows that the supplementation of organic sources of $\mathrm{Zn}, \mathrm{Cu}$ and Se to dairy cows reduced subclinical mastitis cases through decreasing milk SCC without altering the serum levels of antioxidant enzymes (Gayathri and

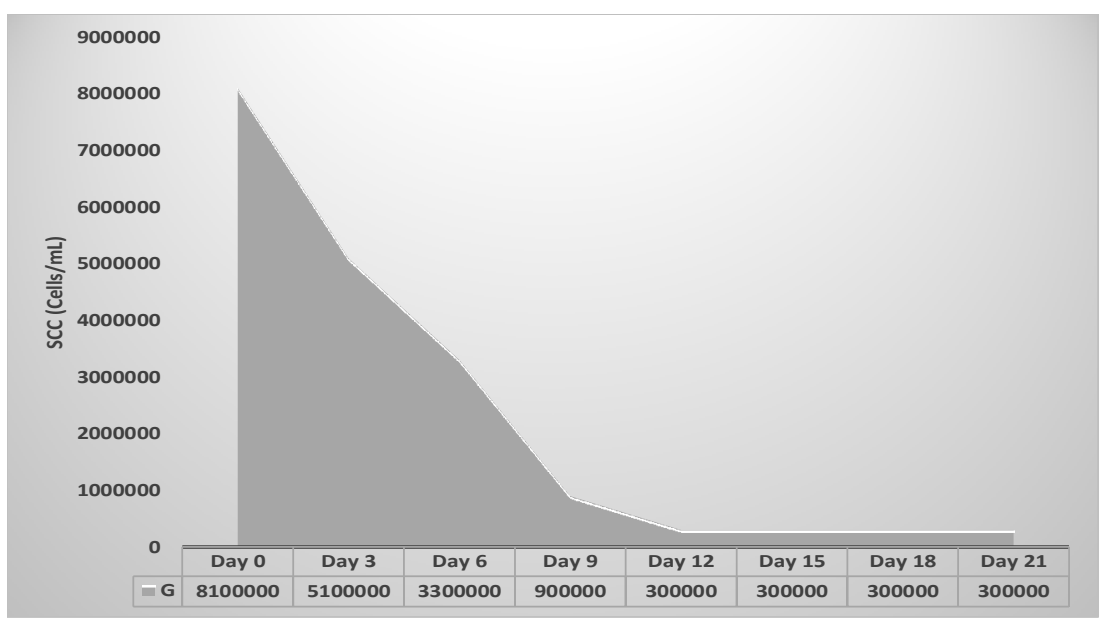

Fig 2: Impact of HimChelate on milk somatic cell. 
Evaluation of Impact of Chelated Mineral Mixture Formulation Supplementation on Milk Quantity and Milk Quality...

Panda. 2018). Moreover, the herb Shatavari (Asparagus racemosus) in HimChelate possesses antibacterial properties against mastitis, causing Streptococci, Coliform, Klebsiella, Pseudomonas (Pandey et al. 2018).

The supplementation of inorganic chromium is difficult because of its poor bioavailability in the feeds (Gayathri and Panda, 2018). Due to this situation, several products based on organic chromium such as Chelated $\mathrm{Cr}$, $\mathrm{Cr}$ enriched yeast, $\mathrm{Cr}$-picolinate, $\mathrm{Cr}$-nicotinate have been developed to improve the bioavailability of chromium (Overton and Yasui. 2014). In ruminant nutrition, Cr plays an important role, especially under stressful conditions, such as stress during transport or stress at the onset of lactation. Some researchers have reported higher performance in calves supplemented with $\mathrm{Cr}$ in $\mathrm{Cr}$ yeast, $\mathrm{Cr}$ chelated during stress (Rao et al. 2012).

Moreover, Bhagwat et al. (2021) recommended developing phytogenic feed additives as a cocktail of organic minerals to improve the overall health status of poultry birds and augment their productivity. Following their concept, HimChelate was developed by Himalaya Wellness Company, Bengaluru, India, to augment the productivity of dairy cows and enhance milk quality. It is mainly composed of chelated minerals and other trace minerals $(\mathrm{Zn}, \mathrm{Cu}, \mathrm{Mn}$, Se, Co, K, Fe, Mg, Cr, Na, Ca and P) and vitamins (A, D3, Eand niacinamide) fortified with herbs, namely, Shatavari (Asparagus racemosus), Amalaki and Methi (Trigonella foenum-graecum). Overall, our study findings indicate that the supplementation of HimChelate impacted the augmentation of milk production and improved milk quality parameters in dairy cows.

\section{CONCLUSION}

Conclusively, the findings of our research investigation depicted that the supplementation of HimChelate at the dose of $30 \mathrm{~g} /$ day/cow impacted in augmentation of milk production and improvement of milk quality parameters. This is because organic chelated minerals of HimChelate are easily bioavailable to lactating dairy cows. In addition, herbal galactogogues, such as Shatavari (Asparagus racemosus) and Methi (Trigonella foenumgraecum), are effective herbal galactogogues and their use as feed additives for dairy animals plays a central role, focus on increasing milk production.

\section{ACKNOWLEDGEMENT}

The authors expressed their deep gratitude to Dr. Rajesh Kumawat, Head - Medical Services and Clinical Development, Dr. U. V. Babu, Head, R\&D Center for guidance and encouragement throughout the study period.

\section{REFERENCES}

Bhagwat, V.G., Balamurugan, E. and Rangesh, P. (2021). Cocktail of chelated minerals and phytogenic feed additives in the poultry industry: A review. Vet. World. 14(2): 364-371.
El Ashry, G. M., Hassan, A. A. M. and Soliman, S.M. (2012). Effect of Feeding a combination of zinc, Manganese and Copper Methionine chelates of early lactation high producing dairy cow. Food and Nutri. Sci. 3: 1084-1091.

Feng J., Ma, W.Q., Niu, H. H., Wu, X. M., Wang, Y. and Feng J. (2010). Effects of zinc glycine chelate on growth, hematological and immunological characteristics in broilers. Biol. Trace Elem. Res. 133: 203-211.

Formigoni, A., Fustini, M., Archetti, L., Emanuele, S., Sniffen, C. and Biagi, G. (2011). Effects of an organic source of copper, manganese and zinc on dairy cattle productive performance, health status and fertility. Ani feed Sci. and Technol. 164(3-4): 191-198.

Gayathri, S. L. and Panda, N. (2018). Chelated minerals and its effect on animal production: A review. Agricultural Reviews. 39(4): 314-320.

Hackbart, K.S., Ferreira, R.M., Dietsche, A.A., Socha, M.T Shaver, R. D., Wiltbank, M. C. and Fricke, P.M. (2010). Effect of dietary organic zinc, manganese, copperand cobalt supplementation on milk production, follicular growth, embryo qualityand tissue mineral concentrations in dairy cows. Jr. Anim. Sci. 88(12): 3856-3870.

Hassan, A.A., El Ashry, Gh. M. and Soliman, S.M. (2011). Effect of supplementation of chelated zinc on milk production in ewes. Food and Nutri. Sci. 2(7): 706-713.

Lisgara, İ., Skampardonis, V. and Leontides, L. (2016). Effect of diet supplementation with chelated zinc, copper and manganese on hoof lesions of loose housed sows. Porcine Health Management. 2(1): 1-9.

Marques, R. S., Cooke, R. F., Rodrigues, M. C., Cappellozza, B. I., Mills, R. R., Larson, C.K. and Bohnert, D.W. (2016). Effects of organic or inorganic cobalt, copper, manganeseand zinc supplementation to late-gestating beef cows on productive and physiological responses of the off spring. Jr. Anim. Sci. 94(3): 1215-1226.

Mirzaei, F. and Venkatesh, H. K. (2012). Efficacy of phyto medicines as supplement in feeding practices on ruminant's performance: A Review. Global Jr. of Res on Med Plants and Ind Med. 1(9): 391.

Overton, T.R. and Yasui, T. (2014). Practical applications of trace minerals for dairy cattle. Jr. of Animal Sci., 92(2): 416-426.

Pandey, A.K., Gupta, A., Tiwari, M., Prasad, S., Pandey, A.N., Yadav, P.K. and Chaube, S.K. (2018). Impact of stress on female reproductive health disorders: Possible beneficial effects of shatavari (Asparagus racemosus). Biomed and Pharmacotherapy. 103: 46-49.

Patel, V.K., Joshi, A., Kalma, R.P., Parmar, S.C., Damor, S.V. and Chaudhary, K.R. (2016). Shatavari (Asparagus racemosus), Jivanti (Leptadenia reticulata) and Methi (Trigonella foenum-graecum): The herbal galactogogues for ruminants. Jr. of Livestock Sci. 7: 231-237.

Patel, V.K., H.D. Chauhan, M.M. Pawar, A.K. Srivastava and Prajapati, K.B. (2017). Effect of Herbal Galactogogue Supplementation on Production Performance of Lactating Kankrej Cows. Int. Jr. of Curr Microbiol App Sci. 6(12): 2093-2098.

Rabiee, A. R., Lean, I. J., Stevenson, M. A. and Socha, M. T. (2010). Effects of feeding organic trace minerals on milk production and reproductive performance in lactating dairy cows: A Meta-Analysis. J. Dairy Sci. 93: 4239-4251. 
Rao, S.V.R., Raju, M.V.L.N., Panda, A.K., Poonam, N.S., Murthy O.K. and Sunder G.S. (2012). Effect of dietary supplementation of organic chromium on performance, carcass traits, oxidative parameters and immune responses in commercial broiler chickens. Bio. Trace Elem. Res. 147: 135-141.

Ravikumar, B.R. and Bhagwat, V.G. (2008). Study of the influence of Galactin Vet Bolus on milk yield in lactating dairy cows. Livestook Line., p. 5-7.

Sharma, A (2010). Influence of polyherbal imunomodulator supplementation on production performance and milk quality of Karanfies cons. Ph.D. Thesis, National Dairy Research Institute, Karna, Hanyana, India

Singh, K, Mshra, KK, Shrivastav, N., Mshra, S.K and Singh, A.K. (2019). Therapeutic efficacy of indigenous polyherbal formulation on milk pH, somatic cell count and electrical resistance profile in healthy and subdinica mastitic dairy cows. Int. J. Ourr. Mcrobid. App. Sci. 8(10): $703-710$.

Sobhanirad, S., Carlson, D. and Kashani, RB. (2010). Effect of zinc methionine or zinc sufate supplementation on milk production and composition of milk in lactating dairy cons. Bio Trace element Res. 136(1): 48-54.
Somkuwar A. P., Kadam, A. S., Shiva Kumar. and Radhakrishna P. M. (2011). Efficacy study of metho-chelated organic minerals preparation feeding on milk production and fat percentage in dairy cows. Vet. World. 4(1): 19-21.

Sukanya, T.S., Rudraswamy, M.S. and Bharathkumar, T.P. (2014). Performance of Shatavari based herbal galactogogueMilkplus supplementation to crossbred cattle of Malnad region. Int. Jr of Sci and Nature. 5(2): 362-363.

Tabares, F.P., Jaramillo, J.V.B. and Ruiz-Cortés, Z.T. (2014). Pharmacological overview of galactogogues. Vet. Med Intl. 2014.

Wang, Y., Tang, J.W., Ma, W.Q., Feng, J. and Feng, J. (2010). Dietary zinc glycine chelates on growth performance, tissue mineral concentrationsand serum enzyme activity in weanling piglets. Bio. Trace Elem. Res. 133: 325-334.

Yatoo, M.I., Saxena, A., Deepa, P.M., Habeab, B.P., Devi, S., Jatav, R.S. and Dimri, U. (2013). Role of trace elements in animals: A review. Vet. World. 6(12): 963-967. 